\title{
President of AMI-2013
}

\author{
Rup Lal
}

Published online: 26 March 2014

(C) Association of Microbiologists of India 2014

It is indeed a great honour and privilege to address the scientific community as the President of one of the oldest and the most reputed scientific associations of the country, The Association of Microbiologists of India (AMI). I feel privileged to address a gathering of microbiologists here at Maharshi Dayanand University, Rohtak on the occasion of the AMI platinum jubilee celebrations.

The Association of Microbiologists of India, since the very day of its conception in 1938, has been actively striving towards augmenting science, especially Microbiology, throughout the country. The AMI has also been promoting microbiology as a multidisciplinary and an indispensable realm of science. During recent years there has been a rapid increase in the enrolment of annual and life members and the academic activities carried out by the AMI. AMI units are now spread across various regions of the country. The entire credit in bringing AMI to this stage goes to my predecessors who had worked very hard especially during 1970s and 1980s to provide a strong foundation to the organization. One of the major events of the AMI has been its annual conference, which is held annually in different regions of India. This event provides a unique platform for exchange of scientific ideas among academicians, researchers and entrepreneurs from different parts of the globe. During recent years we have increased the participation of young students, both at the Undergraduate (UG) and Postgraduate (PG) level by providing them various incentives. Towards this end, we have also invited the thirteen-year old wonder girl, Shushma Verma, who broke all records and qualified her secondary and senior secondary examination at the age of seven and nine, respectively.

\section{R. Lal ( $\square)$}

Molecular Biology Laboratory, Department of Zoology,

University of Delhi, Delhi 110007, India

e-mail: ruplal@gmail.com
Following this she completed her graduation at the mere age of thirteen and is now pursuing a Master's program in Microbiology from Babasaheb Bhimrao Ambedkar University.

The AMI and its leadership are fully aware of the enormous change that microbiology has undergone during recent years and the tremendous role that microbiology plays for the benefit of mankind. Needless to mention that next generation sequencing technologies have played a huge role in changing the face of microbiology in the past few years. With a recent decrement in sequencing costs, the field of genomics and metagenomics has been brought to the forefront of biological sciences. Subsequent to the success of the human genome project, the Human Microbiome project was concluded last year in July. The project revealed:

1. The human body at the time of birth contains 10 trillion cells and 23,000 genes.

2. Bacteria are added to the human system right from birth: 100 trillion bacteria with 3 million non-human genes.

3. $\sim 3 \mathrm{lbs}$ of microbes occupy the human gut! $>500$ different bacterial species in intestine.

4. $60 \%$ of stool dry matter is microbial mass.

5. These bugs are neither parasites nor passengers but are beneficial to human being.

Any imbalance in microbial population in the body can lead to

1. Obesity leanness and malnutrition

2. Diabetes and heart diseases

3. Asthma

4. Liver diseases and bowl cancer and autism

The above lines about the microbiome project are sounding out of place but as a president of the association, I 
would like to point out that we have not made any significant contribution in the areas of genomics and metagenomics. Keeping this in view the organizers of the conference have very vigilantly designed the topics of the conference and brought in speakers from upcoming fields such as genomics, metagenomics, biodiversity, nano-biotechnology, medical microbiology and bioprocess engineering. The number of students venturing into these recent areas in the field of microbiology is increasing year after year and I am happy to tell you that we have already confirmed more than 2,000 participants for this platinum jubilee celebration. I am ecstatic on behalf of all my fellow AMI office bearers to see such an overwhelming response!

I would also like to mention that AMI has been publishing a quarterly journal, "The Indian Journal of Microbiology (INJM)" for the last 54 years. When I took over as an Editor in Chief of INJM, we started publishing it in association with Springer India Ltd. Needless to say that INJM has now acquired a better place in the international community of microbiologists. We still need to do a lot in order to bring it at par with many of the microbiology journals of international repute.

To promote microbiology across the globe, AMI has also joined hands with the American Society for Microbiology (ASM) and is now spreading its wings to collaborate with several more associations. These collaborative efforts are turning to be rewarding in bringing out more such participations from other international academic societies and in near future we further intend to strengthen and expand this network. Ideas and research potential from members across these organizations have the power to stimulate young minds and it is my belief that Indian students will benefit from such collaborations!

At the end, on behalf of AMI and my behalf, I would like to express my sincere gratitude to Shri Bhupinder Singh Hooda Honorable Chief Minister of Haryana for agreeing to our request to be a part of this inaugural function. I would like to convey special thanks to Professor Dinesh Singh, Vice Chancellor, University of Delhi, for joining us at the conference. My interaction with him revealed his strong commitment for empowering Indian youth by reforming education system in India. He knows the level of commitment that is needed to change the education system. He has demonstrated this by introducing the four year Under Graduate Program (4 YUG) in the University of Delhi against all odds. His strong commitment along with his bright ideas won over all the other barriers during this process.

I will be failing in my duties if I do not thank the organizers, especially the Vice Chancellor of Maharshi Dayanand University, Dr Har Sarup Chahal for providing every support to organize the annual conference here. I congratulate Dr. Pratyoosh Shukla and other organizers for such a wonderful effort and once again I welcome all the national and international delegates and wish the conference all success. 